\title{
A Plasmodium falciparum copper-binding membrane protein with copper transport motifs
}

\author{
David L Choveaux', Jude M Przyborski ${ }^{2}$ and JP Dean Goldring ${ }^{1 *}$
}

\begin{abstract}
Background: Copper is an essential catalytic co-factor for metabolically important cellular enzymes, such as cytochrome-c oxidase. Eukaryotic cells acquire copper through a copper transport protein and distribute intracellular copper using molecular chaperones. The copper chelator, neocuproine, inhibits Plasmodium falciparum ring-to-trophozoite transition in vitro, indicating a copper requirement for malaria parasite development. How the malaria parasite acquires or secretes copper still remains to be fully elucidated.

Methods: PlasmoDB was searched for sequences corresponding to candidate P. falciparum copper-requiring proteins. The amino terminal domain of a putative $P$. falciparum copper transport protein was cloned and expressed as a maltose binding fusion protein. The copper binding ability of this protein was examined. Copper transport protein-specific anti-peptide antibodies were generated in chickens and used to establish native protein localization in $P$. falciparum parasites by immunofluorescence microscopy.
\end{abstract}

Results: Six P. falciparum copper-requiring protein orthologs and a candidate $P$. falciparum copper transport protein (PF14_0369), containing characteristic copper transport protein features, were identified in PlasmoDB. The recombinant amino terminal domain of the transport protein bound reduced copper in vitro and within Escherichia coli cells during recombinant expression. Immunolocalization studies tracked the copper binding protein translocating from the erythrocyte plasma membrane in early ring stage to a parasite membrane as the parasites developed to schizonts. The protein appears to be a PEXEL-negative membrane protein.

Conclusion: Plasmodium falciparum parasites express a native protein with copper transporter characteristics that binds copper in vitro. Localization of the protein to the erythrocyte and parasite plasma membranes could provide a mechanism for the delivery of novel anti-malarial compounds.

Keywords: Malaria, Copper transporter, Permeome, PEXEL-negative

\section{Background}

Malaria is a serious, acute and chronic relapsing infection that kills close to one million people annually. More than $90 \%$ of these deaths are recorded in the subSaharan regions of Africa, with the majority being children under the age of five years [1]. Human mortality, as a result of malaria infection, is predominantly caused by Plasmodium falciparum. Efforts to prevent and control the disease have, however, been hindered by an increased parasite resistance to currently available anti-malarial drugs, highlighting the need for novel anti-malarial drug development [2]. A group of proteins gaining increased

\footnotetext{
* Correspondence: goldringd@ukzn.ac.za

${ }^{1}$ Biochemistry, University of KwaZulu-Natal, P.B. X01, Carbis Road, Scottsville 3209, South Africa

Full list of author information is available at the end of the article
}

interest as potential therapeutic targets are the integral membrane proteins predicted to possess transport functions [3,4]. Despite these proteins playing key roles in Plasmodium parasite growth and replication [4], they remain poorly understood and underexploited [3]. Previous studies employing the intracellular copper chelator neocuproine established that copper is an essential micronutrient for in vitro parasite growth [5]. Rasoloson et al. [5] described the membrane-bound PfCuP-ATPase copper efflux protein and suggested this protein acts to reduce copper toxicity in $P$. falciparum. Studying $P$. falciparum copper metabolism may lead to the identification of novel anti-malarial drug targets.

Copper is an essential micronutrient that plays important catalytic and structural roles in numerous enzymes.




Cuproenzymes harness the ability of copper to cycle between a stable oxidized $\mathrm{Cu}(\mathrm{II})$ and unstable reduced $\mathrm{Cu}(\mathrm{I})$ state for various redox reactions. However, this property also makes copper potentially toxic to cells since it can undergo free radical producing Fenton chemistry [6]. Consequently, cells have evolved homeostatic mechanisms for the uptake, distribution, sequestration and secretion of copper to meet essential cellular requirements while reducing its toxic potential. From yeast to humans, copper acquisition is mediated by the high affinity copper transport protein, Ctr1 $[7,8]$. Copper metallochaperones subsequently distribute intracellular copper to specific proteins or organelles. The copper chaperone for superoxide dismutase (CCS) distributes copper to cuprozinc superoxide dismutase ( $\mathrm{Cu} / \mathrm{Zn} \mathrm{SOD}$ ) in the cytosol and mitochondrion, antioxidant protein 1 (Atox1) transfers copper to the secretory pathway and nucleus and an ensemble of proteins deliver copper to cytochrome-c oxidase (CCO) in the mitochondrion $[7,8]$. It has been suggested that $\mathrm{Cu}$-ATPase-mediated secretion of excess copper is the main factor regulating copper homeostasis [9]. Equally important to mammalian growth and development, however, is the copper transporter Ctr1. Cell-specific knock-out of Ctr1 in mouse intestinal epithelial cells caused marked growth retardation, coupled with cardiac hypertrophy and overall viability defects that caused postnatal lethality around three weeks of age [10]. Similarly, knock-out of the Drosophila melanogaster Ctr1A gene resulted in developmental arrest at early larval stages [11]. The $\mathrm{C}$ terminus of yeast copper transport protein, Ctr1, appears to have a role in copper regulation and stopping the build-up of copper to toxic concentrations [12].
Although a $P$. falciparum P-type ATPase copper efflux protein has been described [5], an additional proteinmediated mechanism for copper acquisition has not. The current study describes a novel membrane-bound $P$. falciparum protein with copper transporter characteristics. A recombinant form of the protein's amino terminal region bound reduced copper in vitro and within E. coli host cells. The native P. falciparum copper transport protein was found to initially localize to the infected erythrocyte membrane, followed by relocation to a parasite membrane through the development of the parasite's erythrocytic cycle.

\section{Methods}

\section{Bioinformatics}

The annotated Plasmodium database [13] was screened for the presence of copper-requiring protein orthologs using a BlastP search. Sequences used to screen the database are listed in Table 1. A putative Plasmodium copper transport protein was identified using the Theileria parva (Muguga stock) polymorphic immunodominant molecule (GenBank:AAA99499) [14] to BlastP screen PlasmoDB. In an effort to support sequence identity, the putative Plasmodium copper transport protein sequences were aligned with characterized copper transporter sequences from Homo sapiens (NCBI:NP_001850), Arabidopsis thaliana (Genbank:BAE98928) and Saccharomyces cerevisiae (Genbank:AAB68064) using the ClustalW ${ }^{\mathrm{TM}}$ server. Transmembrane domains were identified in the putative Plasmodium copper transporters using the HMMTOP [15] and TMHMM 2.0 [16] topology prediction servers. The presence of potential signal sequences in each protein was established using the

Table 1 Copper-dependent protein orthologs to Homo sapiens proteins identified in the $P$. falciparum proteome

\begin{tabular}{|c|c|c|c|}
\hline Enzyme name & Accession number & P. falciparum ortholog identified & PlasmoDB protein identifier \\
\hline$\overline{C C S}$ & CAG46726 & No & N/A \\
\hline Cu/Zn Superoxide dismutase & AAB05661 & No & N/A \\
\hline Dopamine- $\beta$-monooxygenase & PO9172 & No & N/A \\
\hline Peptidylglycine monooxygenase & P19021 & No & N/A \\
\hline Metallothionein & AAP97267 & No & N/A \\
\hline S-adenosyl-L-homocysteine hydrolase & P23526 & Yes & PFE1050w \\
\hline Cox11 & CAG46636 & Yes & PF14_0721 \\
\hline Cox17 & AAA98114 & Yes & PF10_0252 \\
\hline Cox19 & AAY35062 & Yes & PFL0090c \\
\hline $\mathrm{Cg} 3$ & O75880 & Yes & PF07_0034 \\
\hline Cytochrome-c oxidase subunit I & ACR77861 & Yes & mal_mito_2 \\
\hline Cytochrome-c oxidase subunit II & $\mathrm{ABU} 47824$ & Yes & PF14_0288 (Illa) PF13_0327 (IIb) \\
\hline Cytochrome-c oxidase subunit III & ABJ99455 & Yes & mal_mito_1 \\
\hline Cytochrome-c oxidase subunit Vb & AAA52060 & Yes & PFI1365W \\
\hline Cytochrome-c oxidase subunit VIb & AAP35591 & Yes & PFI1375w \\
\hline
\end{tabular}


TMHMM server and the SignalP 3.0 program (Center for Biological Sequence Analysis, Lyngby, Denmark). A cladogram was generated from a ClustalW ${ }^{\mathrm{mm}}$ alignment of six putative Plasmodium copper transporters with seven characterized copper transporters. The characterized transporters were from Homo sapiens, Mus musculus (NCBI:NP_780299), Rattus norvegicus (NCBI:NP_598284), Danio rerio (NCBI:NP_991280), Arabidopsis thaliana, Saccharomyces cerevisiae and Theileria parva.

\section{Antibody production and purification}

The amino acid sequence for a putative $P$. falciparum copper transport protein (PF14_0369) was retrieved from PlasmoDB and subjected to Predict7 [17] analysis to identify immunogenic regions and the peptide CNLQKEEDTVVQLQD was selected for synthesis (GL Biochem Ltd. Shanghai, China). The selected peptide was coupled to rabbit albumin via the native amino terminal cysteine residue using $\mathrm{m}$-maleimidobenzoyl$\mathrm{N}$-hydroxysuccinimide ester. Hy-Line Brown hens were used for antibody generation and antibodies were isolated from egg yolk as previously described $[18,19]$. Animal ethics clearance was obtained from the University of KwaZulu-Natal animal ethics committee (003/10/ Animal).

\section{PCR amplification and cloning}

Plasmodium falciparum (D10) gDNA was isolated from infected red blood cells using the Fermentas ${ }^{\mathrm{TM}}$ DNA purification kit. The full-length PF14_0369, open reading frame was amplified using the following specific primers: PfCtr369-fwd: 5'-atGAATTCGACAAAAGCGACAATA GTATTTG-3' and PfCtr369FL-rev: 5'-ACATCCACAA CAAGCTGGATC. For functional copper binding studies, the coding domain for the protein's amino terminal domain minus signal peptide was amplified using the PfCtr369-fwd primer containing an engineered EcoRI cleavage site and PfCtr369Nt-rev: 5'-caCTGCAGTTAC GATTTGGTTTCCCATTTG-3' containing a Pst cleavage site (cleavage sites underlined). PCR products were analyzed on a $1 \%(\mathrm{w} / \mathrm{v})$ agarose gel. The PCR amplicon for the PF14_0369 amino terminal domain (designated $\mathrm{Nt})$ minus signal peptide $\left(P f C \operatorname{ct} 369 \mathrm{Nt}^{-\mathrm{S}}\right.$ ) was cloned in frame with the maltose binding protein (MBP) gene in the pMal-p2x bacterial expression vector (New England BioLabs, USA), as previously described [18].The integrity of the resultant pMal-p2x/PfCtr369Nt ${ }^{-\mathrm{S}}$ plasmid insert was confirmed by DNA sequencing. Using the strategy employed for pMal-p2x/PfCtr369 $\mathrm{Nt}^{\mathrm{S}}$, a plasmid containing pMal-p2X/PfCtr211 $\mathrm{Nt}^{-\mathrm{S}}$ from the PF14_0211 gene was prepared.

\section{Expression and purification of recombinant MBP-PfCtr369Nt ${ }^{-\mathrm{S}}$}

A single E. coli JM103[pMal-p2x/PfCtr369Nt ${ }^{-S}$ ] colony was grown overnight at $30^{\circ} \mathrm{C}$ in sterile LB medium supplemented with $100 \mu \mathrm{g} \cdot \mathrm{ml}^{-1}$ ampicillin. The overnight culture was diluted in fresh broth, plus antibiotic, and incubated at $30^{\circ} \mathrm{C}$ until the $\mathrm{A}_{600}$ reached $~ 0.6$. MBP$P f C$ tr $369 \mathrm{Nt}^{-\mathrm{S}}$ expression was induced with $0.3 \mathrm{mM}$ IPTG and the cultures grown for a further $16 \mathrm{~h}$ before harvesting of cells by centrifugation $\left(4000 \mathrm{~g}, 15 \mathrm{~min}, 4^{\circ} \mathrm{C}\right)$. The E. coli periplasmic content was isolated following the method described by French et al. [20] and the recombinant protein purified by amylose affinity chromatography. Recombinant MBP-PfCtr211Nt ${ }^{-\mathrm{S}}$ was expressed using the same procedure. Protein samples were analyzed on a $12.5 \%$ SDS-PAGE gel [21] followed by Western blotting and probed with chicken anti-PF14_0369 and antiMBP antibodies [22] (see below). Protein concentration was determined with the Bradford dye-binding protein assay, using ovalbumin as the standard [23].

\section{Parasite culture}

Plasmodium falciparum 3D7 parasites were cultured in human $\mathrm{O}^{+}$erythrocytes according to standard protocols, except cultures were incubated in gassed flasks [24]. Synchronized asexual parasites were obtained by sorbitol treatment [25].

\section{Western blot analyses}

For Western blot analyses of P. falciparum lysates, protein samples were prepared from saponin-isolated, sorbitol-synchronized parasites. Equivalent amounts of $1 \times 10^{7}$ parasites were analysed by $12.5 \%$ SDS-PAGE and transferred to a nitrocellulose membrane. Primary chicken anti-PF14_0369 and chicken anti-P. falciparum lactate dehydrogenase (LDH) antibodies against specific peptides on each protein were employed and detected using rabbit anti-chicken horseradish peroxidaseconjugated secondary antibodies (DAKO, Santa Cruz). Immunoblots were developed using enhanced chemiluminescence. Recombinant MBP-PfCtr369Nt ${ }^{-S}$ expression was analysed by Western blot using chicken anti-MBP and anti-PF14_0369 anti-peptide antibodies. These antibodies were detected using rabbit anti-chicken horseradish peroxidase-conjugated secondary antibodies (Jackson Immuno-Research Laboratories, USA) and visualized by incubating the membrane in $0.06 \%(\mathrm{w} / \mathrm{v})$ 4-chloro-1naphthol and $0.0015 \%(\mathrm{v} / \mathrm{v}) \mathrm{H}_{2} \mathrm{O}_{2}$.

\section{Copper binding}

For in vitro copper binding studies, purified MBPPfCtr369 $\mathrm{Nt}^{-\mathrm{S}}(10 \mu \mathrm{M})$ was mixed with $200 \mu \mathrm{M} \mathrm{CuCl}$, with or without $10 \mathrm{mM}$ ascorbic acid, and incubated at RT for $15 \mathrm{~min}$. Unbound copper was removed by 
overnight dialysis against sodium phosphate buffer [0.1 $\left.\mathrm{M} \mathrm{NaH}_{2} \mathrm{PO}_{4}, 0.01 \%(\mathrm{w} / \mathrm{v}) \mathrm{NaN}_{3}, \mathrm{pH} 7.5\right]$ at $4^{\circ} \mathrm{C}$. Copper binding to MBP-PfCtr369Nt $\mathrm{Nt}^{-\mathrm{S}}$ and the oxidation state of bound copper was assessed using the bicinchoninic acid (BCA) assay [26], in which protein-copper complexes are disrupted by acid denaturation and copper detected upon release. BCA binds reduced copper $\left(\mathrm{Cu}^{+}\right)$, forming a purple complex detectable at $354 \mathrm{~nm}$. If copper is present in solution as $\mathrm{Cu}^{2+}$, ascorbate must be added to the sample following acid denaturation to yield a $\mathrm{Cu}^{+}$-BCA complex. However, if the addition of ascorbate does not influence $\mathrm{Cu}^{+}-\mathrm{BCA}$ complex formation, this indicates copper was released from the protein in the $\mathrm{Cu}^{+}$state. Solutions of $\mathrm{CuCl}_{2}$ in sodium phosphate buffer were used as standards and affinity purified MBP served as a negative control. The ability of MBP$P f C t r 369 \mathrm{Nt}^{-\mathrm{S}}$ to bind copper within E. coli cells was also examined. Cells containing the recombinant protein were grown in the presence or absence of $0.5 \mathrm{mM} \mathrm{CuCl}_{2}$, and the recombinant protein purified as described above. Prior to cell disruption and MBP-PfCtr369 $\mathrm{Nt}^{-\mathrm{S}}$ isolation, pelleted cells were washed with a Tris buffer $(0.2 \mathrm{M}$ Tris- $\mathrm{HCl}, \mathrm{pH} 7.5$ ) to remove extraneous $\mathrm{CuCl}_{2}$. As with in vitro copper binding, copper bound to MBP$P f C t r 369 \mathrm{Nt}^{-\mathrm{S}}$ within $E$. coli cells was detected using the BCA assay.

\section{Ascorbate oxidation assay}

The ability of MBP-PfCtr369Nt ${ }^{-\mathrm{S}}$ to inhibit the coppercatalysed oxidation of ascorbic acid $\left(\mathrm{H}_{2} \mathrm{Asc}\right)$ was tested in vitro. In a typical experiment a mixture was prepared containing $5 \mu \mathrm{M}$ MBP-PfCtr369Nt ${ }^{-\mathrm{S}}$, or $5 \mu \mathrm{M} \mathrm{MBP}$


adjusted to $\mathrm{pH} 4.5$ with $\mathrm{NaOH}$. The absorbance of this solution was monitored at $255 \mathrm{~nm}$ with readings taken every $5 \mathrm{~s}$ for $300 \mathrm{~s}$. Reactions were carried out at RT.

\section{Immunofluorescence}

Immunofluorescence assays were carried out following cell fixation with $4 \%$ paraformaldehyde $/ 0.00075 \%(w / v)$ glutaraldehyde as previously described [27] except fixation was carried out at $37^{\circ} \mathrm{C}$ for 30 minutes and quenching was performed with $125 \mathrm{mM}$ glycine/PBS. Chicken anti-peptide antibodies directed against $P$. falciparum lactate dehydrogenase and PF14_0369 and a rabbit antibody against Exp-1 were used. Primary antibodies were diluted in $3 \%(\mathrm{w} / \mathrm{v})$ BSA/PBS and detected with either goat anti-chicken-Cy3 or goat anti-rabbit-Cy2 antibodies (DAKO, Santa Cruz). Hoechst 33258 (Molecular probes) was used at a concentration of $50 \mathrm{ng} \cdot \mathrm{ml}^{-1}$ to stain parasite DNA. All images were acquired at room temperature on a Zeiss Cell Observer using appropriate filter sets.

\section{Results}

Identification of copper-dependent protein orthologs in the $P$. falciparum proteome

Cytochrome-c oxidase (CCO) is a key multi-subunit catabolic protein containing three functionally important copper ions in its binuclear $\mathrm{Cu}_{\mathrm{A}}$ and mononuclear $\mathrm{Cu}_{\mathrm{B}}$ sites [28]. Metallation of the $\mathrm{Cu}_{\mathrm{A}}$ and $\mathrm{Cu}_{\mathrm{B}}$ sites requires the copper metallochaperones Cox17, Sco1 and Cox11 [29]. Identification of $P$. falciparum orthologs of these metallochaperones and other related copper-requiring proteins supports a plasmodial requirement for copper, as previously suggested [5]. A BlastP search of PlasmoDB, using mammalian and yeast proteins, identified six copper binding protein orthologs (Table 1). These were Cox11, Cox17, Cox19, Sco1, five CCO subunits and S-adenosyl-L-homocysteine hydrolase. The identification of CCO subunit I and II orthologs appears most important since these house the binuclear $\mathrm{Cu}_{\mathrm{A}}$ and mononuclear $\mathrm{Cu}_{\mathrm{B}}$ copper binding sites [28]. Interestingly, the $P$. falciparum proteome appears to lack an identifiable class of metallothioneins and $\mathrm{Cu} / \mathrm{Zn}$ SOD (Table 1). In yeast and mammalian cells, these proteins are essential for copper storage and free radical detoxification, respectively $[7,8]$.

\section{Identification of a putative Plasmodium copper transport protein}

Although P. falciparum appears to require copper for survival [5], the mechanism by which the parasite acquires copper remains to be formally identified. One suggested mechanism is acquisition via the ingestion and digestion of host erythrocyte $\mathrm{Cu} / \mathrm{Zn}$ SOD [5]. A potential alternate mechanism is acquisition via a copper transport protein. The Theileria parva polymorphic immunodominant molecule sequence [14], which possesses copper transport protein features, was used to screen PlasmoDB for a candidate Plasmodium copper transport protein. Full length, putative copper transporter sequences were identified for six Plasmodium species, namely Plasmodium falciparum (PF14_0369 and PF14_0211), Plasmodium vivax (PVX_118540), Plasmodium yoelIi (PY00413), Plasmodium berghei (PBANKA_130290), Plasmodium chabaudi (PCHAS_ 130610), and Plasmodium knowlesi (PKH_126730). Incomplete sequences possessing copper transporter features were identified for Plasmodium gallinaceum (Pgal0564e04) and Plasmodium reichenowi (reich164f12.q1k). Analysis of the complete Plasmodium sequences with HMMTOP [15] and TMHMM [16] identified at least three putative transmembrane domains and a signal peptide in the sequences (Figure 1A). The Plasmodium copper transport protein sequences contain characteristic features of the copper transport protein family, including three transmembrane domains, copper-binding methionine motifs within the 


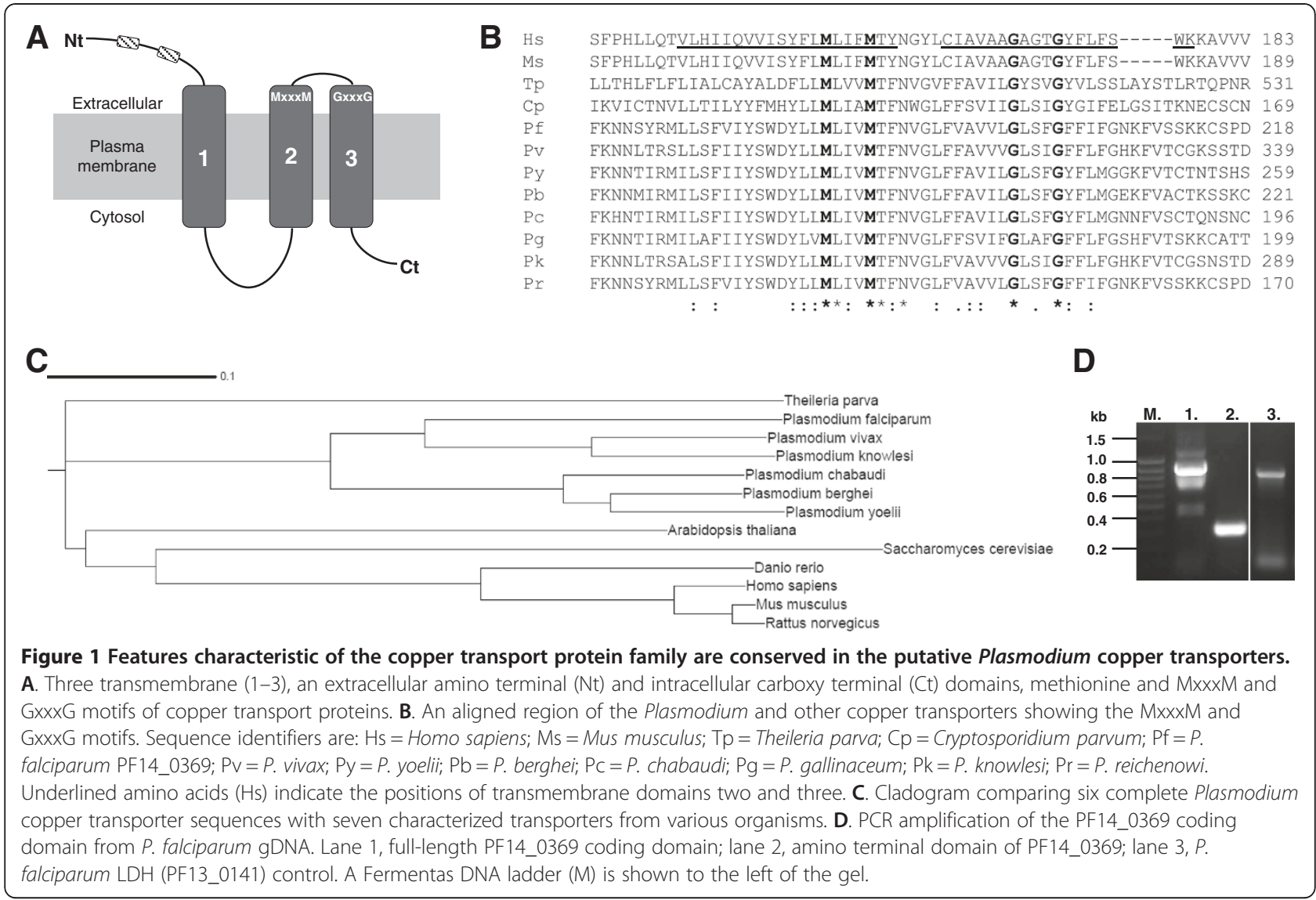

extracellular amino-terminal domain (Figure 1A) and the essential MxxxM $\left(\mathrm{Mx}_{3} \mathrm{M}\right)$ and $\operatorname{GxxxG}\left(\mathrm{Gx}_{3} \mathrm{G}\right)$ motifs (Figure 1B) in the second and third transmembrane domains respectively. An essential methionine residue, located 20 amino acid residues from the first putative transmembrane domain [30], is present in all the Plasmodium sequences (Additional file 1).

A cladogram was generated for the complete Plasmodium copper transporters to compare their similarity to seven characterized copper transporters. The Plasmodium copper transporters formed a cluster related to, but separate from, the characterized copper transporters (Figure 1C). Of the characterized transporters, the sequence with the greatest similarity to that of Plasmodium parasites was from Theileria parva. This was to be expected since $T$. parva belongs to the same phylum as Plasmodium parasites, the Apicomplexans [31]. Closer analysis of the Plasmodium sequences indicated that the three rodent-infecting malaria parasites cluster together, whilst $P$. vivax, $P$. knowlesi and $P$. falciparum form a separate but related cluster. Similar relationships have been observed from a phylogenetic analysis of the Plasmodium cytochrome-b and small subunit rRNA sequences [32]. The separate cluster of the mammalian, yeast and plant reference sequences suggests a more distant similarity to the Plasmodium sequences.
Considering its clinical importance, $P$. falciparum was selected for further studies of the putative copper transporter. The gene encoding the putative copper transport protein (PF14_0369) is located on the positive strand of chromosome 14 as a two-exon gene with a 336 bp first exon and $372 \mathrm{bp}$ second exon, translating to a 235 amino acid protein with a predicted mass of $27.15 \mathrm{kDa}$. The full length and amino terminal coding domain coding sequences for the putative $P$. falciparum copper transport protein (PF14_0369) were PCR amplified from genomic DNA, producing amplicons of approximately $890 \mathrm{bp}$ and $290 \mathrm{bp}$, respectively (Figure 1D). An $820 \mathrm{bp}$ product was amplified for the LDH control (Figure 1D). The identity of the amplicon for the putative transporter's amino terminal domain (PfCtr369 $\left.\mathrm{Nt}^{-\mathrm{S}}\right)$ was confirmed by sequencing. This amplicon was cloned and expressed as a MBP fusion partner (MBP-PfCtr369Nt $\left.{ }^{-\mathrm{S}}\right)$.

\section{Recombinant expression of MBP-PfCtr369Nt ${ }^{-\mathrm{S}}$}

The amino terminal domain of yeast and mammalian copper transport proteins is essential for copper acquisition [33], hence the corresponding domain of the putative $P$. falciparum copper transporter was selected for copper binding studies. A similar approach has been adopted for characterization of the PfCuP-ATPase 
copper efflux pump [5]. To limit the possibility of recombinant MBP-PfCtr369 $\mathrm{Nt}^{-\mathrm{S}}$ associating with a bacterial membrane, the predicted signal peptide was omitted and denoted as "-S" [34]. Expression of a $55 \mathrm{kDa}$ protein was induced from the MBP-PfCtr369 $\mathrm{Nt}^{-\mathrm{S}}$ plasmid and affinity purified from the bacterial periplasmic contents using an amylose affinity matrix (Figure 2A). The size of the purified protein corresponded well with that predicted from the cloned sequence $(54 \mathrm{kDa})$. An additional $42 \mathrm{kDa}$ product, in the purified MBP-PfCtr369Nt ${ }^{-\mathrm{S}}$ fraction, is likely to be MBP lacking the fused protein. A Western blot using anti-MBP antibodies recognizes both the $42 \mathrm{kDa}$ and $55 \mathrm{kDa}$ bands (Figure 2B), whilst antibodies specific for $P f C t r 369 \mathrm{Nt}^{-\mathrm{S}}$ only recognize the $55 \mathrm{kDa}$ band (Figure 2C). Also evident in the anti-MBP (Figure 2B) and anti-PfCtr369 $\mathrm{Nt}^{-\mathrm{S}}$ blots (Figure 2C) are additional truncated forms of MBP-PfCtr $369 \mathrm{Nt}^{-\mathrm{S}}$ between the $55 \mathrm{kDa}$ and $42 \mathrm{kDa}$ bands. Recombinant MBP-PfCtr211 $\mathrm{Nt}^{-\mathrm{S}}$ was expressed as a $46 \mathrm{kDa}$ protein (Additional file 2).

\section{MBP-PfCtr369Nt ${ }^{-5}$ binds copper}

In yeast and mammalian cells, copper appears to be transported across the membrane in its reduced form $\left(\mathrm{Cu}^{+}\right)$[30] and hence a $\mathrm{Cu}^{+}$preference was examined for the putative $P$. falciparum copper transporter. Purified MBP-PfCtr369Nt ${ }^{-\mathrm{S}}$ was incubated with $\mathrm{CuCl}_{2}$ in the presence or absence of the reducing agent ascorbate. Unbound copper was removed by dialysis and the bound copper detected using the BCA assay [26] with or without a second treatment of ascorbate. If ascorbate was required in the $\mathrm{BCA}$ assay for the formation of a purple complex it suggests $\mathrm{Cu}^{2+}$ is preferentially bound. Alternatively, if ascorbate supplementation was not required for colour formation then $\mathrm{Cu}^{+}$is suggested to be the preferred substrate. Purified MBP-PfCtr369Nt ${ }^{-\mathrm{S}}$ showed a binding preference for $\mathrm{Cu}^{+}$in vitro (Figure 3A). Exclusion of ascorbate from the initial $\mathrm{CuCl}_{2}$ incubation resulted in low levels of detectable copper (Figure 3A), whereas including ascorbate resulted in a $~ 70 \%$ increase $(\mathrm{p}<0.01)$ in the amount of copper detected. The absence of ascorbate from the BCA assay did not affect $\mathrm{BCA}-\mathrm{Cu}^{+}$ complex formation for the sample originally incubated with ascorbate, thereby supporting a preference for $\mathrm{Cu}^{+}$ (Figure 3A).

The ability of MBP-PfCtr369Nt ${ }^{-S}$ to bind copper within a cellular environment was examined by expressing the protein in the presence of $0.5 \mathrm{mM} \mathrm{CuCl}_{2}$. This concentration of copper does not affect $E$. coli growth [35]. MBP-PfCtr369Nt ${ }^{-S}$ isolated and affinity purified from E. coli cells grown in copper-enriched media, bound copper (Figure 3B). Extraneous copper was removed by washing the cells prior to protein isolation. Protein isolated from cells grown without copper had negligible amounts of copper present $(\mathrm{p}<0.01)$ (Figure 3B). The oxidation state of copper bound within the cell was inferred by including or excluding ascorbate from the BCA assay (Figure 3B). Like the in vitro analysis, $\mathrm{Cu}^{+}$appeared to be the preferred oxidation state bound by the protein within the E. coli periplasm. An interesting consequence when copper was added to the $E$. coli growth medium was a four-fold increase in MBPPfCtr369 $\mathrm{Nt}^{-\mathrm{S}}$ yield from $1.53 \mathrm{mg}$ to $5.98 \mathrm{mg}$ per litre of culture $(\mathrm{p}<0.01)$ (Figure $3 \mathrm{~B}$, inset). In all experiments MBP served as a negative control. Recombinant MBP did not bind copper and $\mathrm{CuCl}_{2}$ had no perceptible influence on MBP expression (Figure 3).

\section{Analysis of copper binding to MBP-PfCtr369Nt ${ }^{-5}$ using the rate of ascorbate oxidation}

By taking advantage of the copper-catalysed oxidation rate of ascorbate and the ability of chelators to affect this rate, Jiang et al. [36] demonstrated that copper transport protein methionine motif peptides bind $\mathrm{Cu}^{+}$ with methionine-only coordination. The effect MBPPfCtr369Nt ${ }^{-\mathrm{S}}$ had on copper-catalysed ascorbate oxidation



Figure 2 Expression and purification of recombinant MBP-PfCtr369Nt ${ }^{-5}$. Expression of MBP-PfCtr369Nt ${ }^{-5}$ was targeted to the E. coli periplasm. A. Steps in the isolation of recombinant MBP-PfCtr369 $\mathrm{Nt}^{-\mathrm{S}}$ were analysed on a $12.5 \%$ reducing SDS-PAGE. Western blot of A. probed with either anti-MBP B. or anti-PF14_0369 antibodies C. In all panels: lane 1, total E. coli lysate; lane 2, periplasmic proteins; lanes 3-5 represent proteins that did not bind, were washed from and eluted off the amylose resin, respectively. Molecular markers are shown to the left of each image. 



Figure $3 \mathrm{MBP}-\mathrm{PfCtr} 369 \mathrm{Nt}^{-\mathrm{S}}$ binds copper in vitro and within E. coli host cells. A. Affinity-purified MBP-PfCtr369Nt ${ }^{-\mathrm{S}}$ or MBP was incubated with $\mathrm{CuCl}_{2}$ in the presence (+) or absence (-) of ascorbic acid in vitro. The BCA release assay detected copper with (solid bars) or without (open bars) the addition of ascorbic acid. The concentration of the copper standard $\left(\mathrm{CuCl}_{2}\right.$ only) was equimolar to the amount of protein used. $\mathbf{B}$. CuCl 2 was added to the E. coli cell growth medium after the induction of recombinant protein expression. Following affinity purification, protein-bound copper was detected using the BCA release assay with (solid bars) or without (open bars) the addition of ascorbic acid. The addition of copper to the E. coli growth medium increased recombinant protein yield (inset). In all panels, MBP serves as a control and * represents statistical significance $(p<0.05)$. Results are means \pm S.D. of triplicate measurements done for duplicate dialysis sacs.

was examined by monitoring the loss of absorbance at $255 \mathrm{~nm}$ of a $120 \mu \mathrm{M}$ ascorbate solution at $\mathrm{pH} 4.5$. This $\mathrm{pH}$ was optimal for several reasons. First, increased concentrations of the ascorbate monoanion ( $\left.\mathrm{HAsc}^{-}\right)$, which has a pKa of 4.1, cause increased oxidation rates thus elevated $\mathrm{pH}$ values can amplify unwanted errors. Second, $\mathrm{Cu}^{2+}$ hydrolysis is minimal at a lower $\mathrm{pH}[36]$. Last, and perhaps more relevant to the amino terminal domain of the putative $P$. falciparum copper transporter, is that the related human $\mathrm{Ctr} 1$ shows increased copper uptake at a low extracellular $\mathrm{pH}$ and yeast cells expressing Ctr1 acidify their media to $\mathrm{pH} 4-5$ [37]. Freshly prepared ascorbate showed a stable absorbance at $255 \mathrm{~nm}\left(\mathrm{~A}_{255}\right)$ over 300 seconds (Figure 4). The addition of $8 \mu \mathrm{M} \mathrm{CuCl}_{2}$ caused a rapid decrease in the $A_{255}$ signal, indicative of oxidation by copper. The copper-catalysed oxidation appeared to be inhibited by the addition of $5 \mu \mathrm{M}$ purified MBP$P f C t r 369 \mathrm{Nt}^{-\mathrm{S}}$ (Figure 4). This suggested MBP-PfCtr369 $\mathrm{Nt}^{-\mathrm{S}}$ chelates copper in solution, thus preventing its participation in the redox cycle of ascorbate oxidation. Although this assay is not definitive of the copper species preferentially bound by MBP-PfCtr369Nt ${ }^{-\mathrm{S}}$, it is presumably $\mathrm{Cu}^{+}$,



Figure $4 \mathrm{MBP}-\mathrm{PfCtr} 369 \mathrm{Nt}^{-\mathrm{S}}$ inhibits the copper-catalysed oxidative degradation of ascorbate. Ascorbate does not auto-oxidize when exposed to air (indicated by the light gray circle). The addition of $\mathrm{CuCl}_{2}$ catalyses the oxidation of the ascorbate solution (indicated by the dark gray diamond), with this oxidation rate reduced by the inclusion of MBP-PfCtr369Nt ${ }^{-5}$ (indicated by the light gray triangle). MBP (indicated by the dark gray square) did not prevent the copper-catalysed oxidation of ascorbate. 
based on results from the other copper-binding studies conducted for MBP-PfCtr369Nt ${ }^{-\mathrm{S}}$ (Figure 3). Control experiments indicated MBP had minimal influence on the copper-catalysed oxidation rate of ascorbate.

\section{Native expression of a putative $P$. falciparum copper transport protein}

An antibody probe specific for the putative $P$. falciparum copper transporter (PF14_0369) was designed to detect the native $P$. falciparum protein. Parasite lysates from sorbitol-synchronized $P$. falciparum parasite cultures were separated by SDS-PAGE (Figure 5A) and transferred to a nitrocellulose membrane. Affinity purified anti-peptide antibodies targeting the N-terminal domain of the putative P. falciparum copper transporter recognized protein bands of $34 \mathrm{kDa}$ and $68 \mathrm{kDa}$ in most stages of sorbitol-synchronized, asexual cultured parasites (Figure 5C). These bands may represent monomeric and dimeric species, as has been suggested for human Ctr1 [37]. Expression of the putative copper transporter appeared to increase in a similar manner to $P f$. LDH as $P$. falciparum progressed through its asexual cycle (Figure $5 \mathrm{~B}$ ). The increase in protein expression is also seen as an increase in PF14_0369 transcription [38].

\section{Localization of a putative $P$. falciparum copper transport protein}

Characterized copper transport proteins are defined as integral membrane proteins that, depending on cell type, localize to either the plasma membrane or intracellular vesicles [8]. Analysis of the PF14_0369 protein sequence predicted an amino terminal signal peptide [39] and an apicoplast targeting signal [40]. Further analysis indicated that PF14_0369 lacked an identifiable PEXEL/HT motif. This suggested the putative copper transporter would be targeted to the parasite's apicoplast and not to the parasite or erythrocyte plasma membranes. To define the protein's native sub-cellular location, the antipeptide antibodies specific for the putative copper transporter were used in immunofluorescence assays. For this assay a modified form of the fixation protocol developed by Tonkin et al. [27] was employed. Advantages of this technique, over the traditional methanol or methanol/acetone fixation methods, include decreased auto-fluorescence and improved preservation of cell morphology [27].

Sorbitol-synchronized parasites at various developmental stages were fixed as described above and probed with specific anti-peptide antibodies. In ring stage parasites, the majority of the fluorescence signal could be detected in close proximity to the erythrocyte plasma

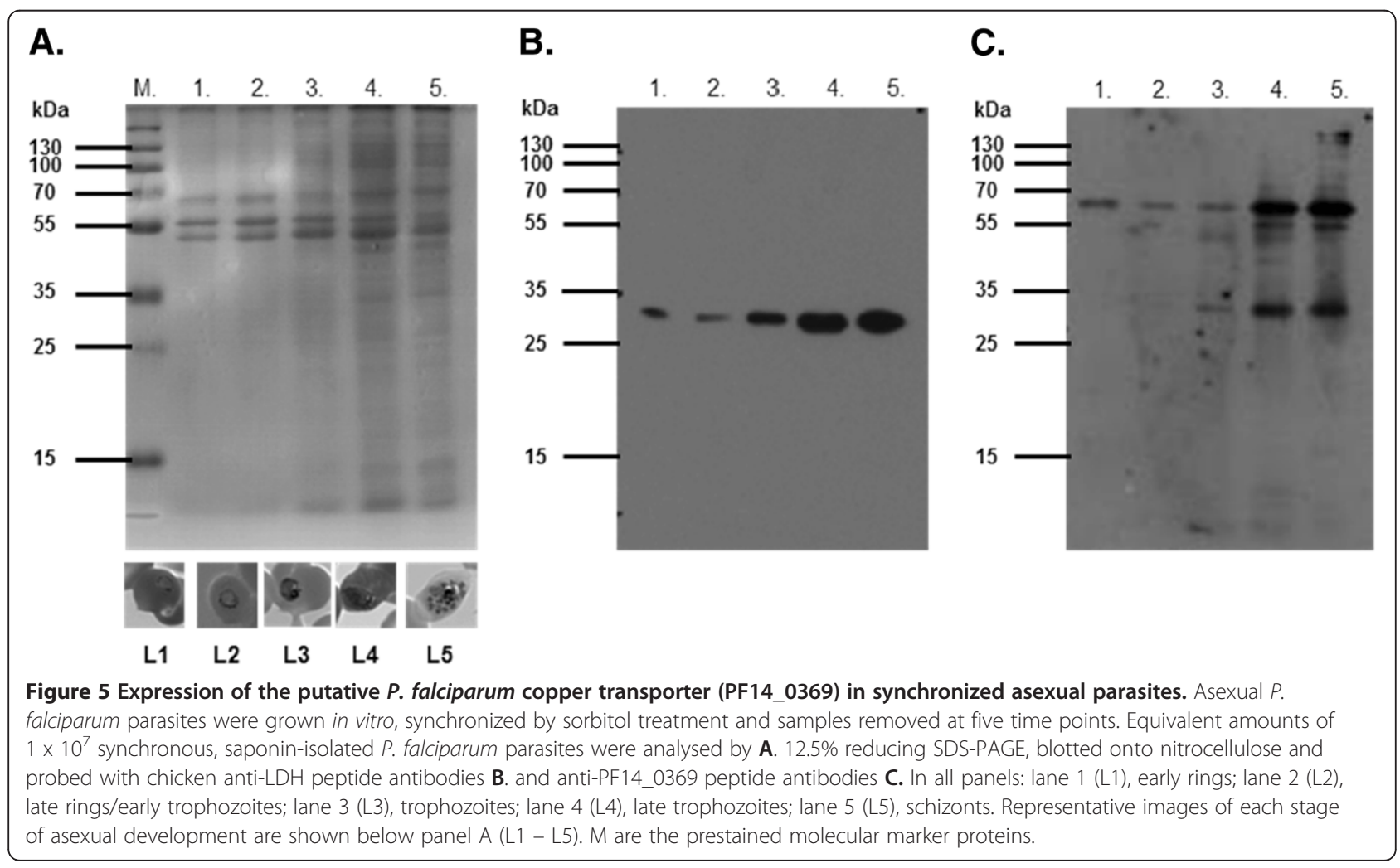




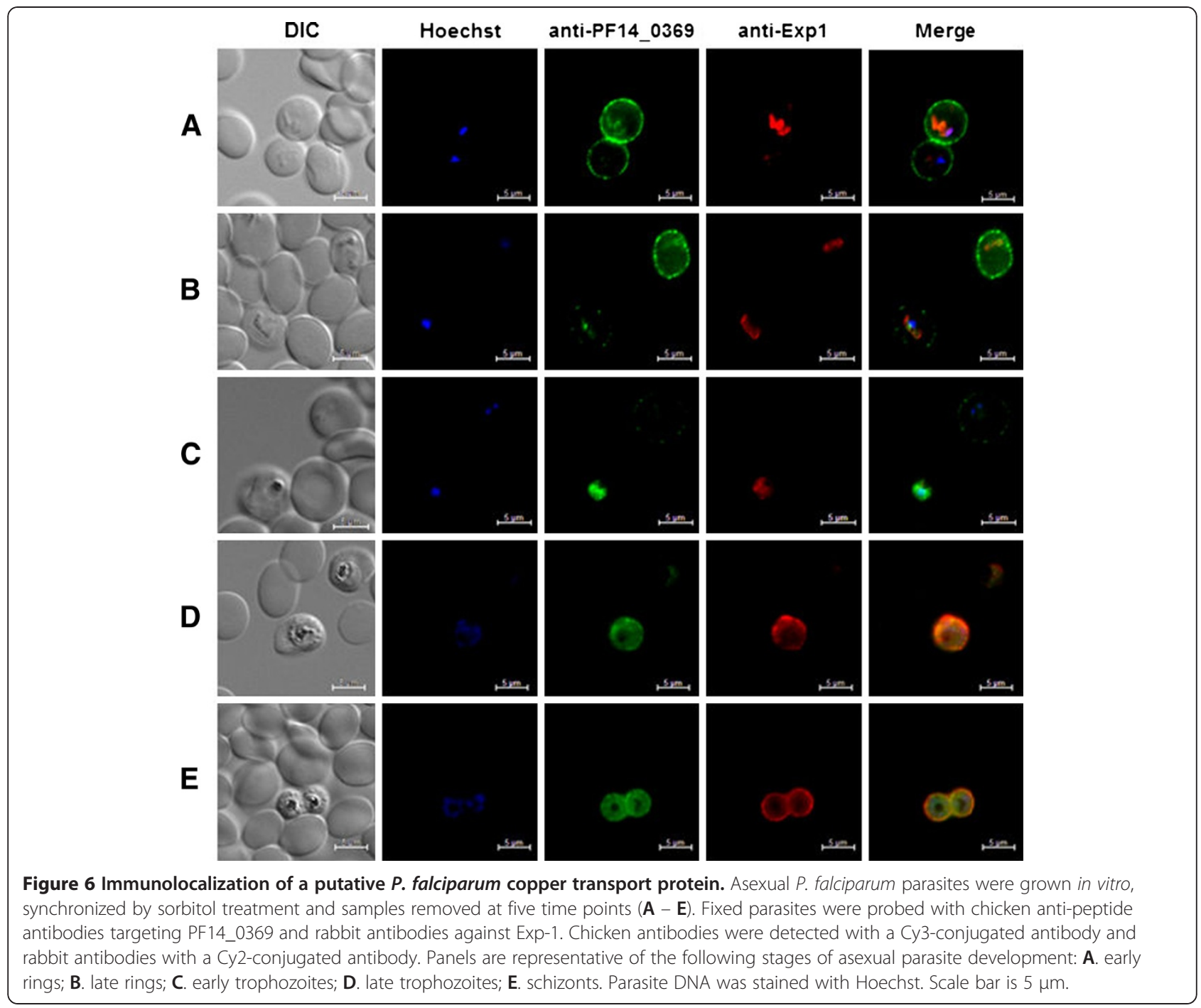

membrane (Figure 6A), with lower amounts of labelling found close to the body of the parasite. The signal associated with the parasite body overlaps considerably with that for Exp-1, a marker of the parasitophorous vacuole membrane [41]. As parasites progressed through the erythrocytic cycle, the erythrocyte plasma membrane staining became progressively weaker, with a concomitant increase in the signal co-localizing with Exp-1 (Figure 6B-E). The specificity of this signal migration becomes even more apparent in panels in which two different parasites of slightly different developmental progression show differing fluorescence phenotypes (Figure 6B and C). Towards the later stages of parasite development, the entire fluorescence signal can be seen in tight association with the parasite itself, with no signal detectable in the erythrocyte (Figure 6D and E). As the copper transporter is predicted to contain apicoplast targeting information, we carried out immuno-colocalization studies using antisera detecting the apicoplast resident protein acyl-carrier protein. Even in parasite stages in which the copper transporter appears to localize with the body of the parasite, no significant signal co-localization was noted. All images were acquired using the same exposure time to allow for direct comparison of signal strength. Control experiments using pre-immune antibody preparations or only secondary antibodies showed no antibody staining and additionally experiments targeting the P. falciparum cytoplasmic proteins LDH, GAPDH and HSP86/90 showed a notably different localization from that of the putative copper transporter. No signal was seen to associate with non-infected erythrocytes (Figure 6A-E).

\section{Analysis of PF14_0369 for novel export signals}

Export of the putative copper transporter to the erythrocyte surface was surprising considering the lack of an identifiable PEXEL/HT motif. Exported P. falciparum proteins lacking a PEXEL motif have previously been 
identified and are termed "PEXEL negative exported proteins" (PNEPs) [42]. Partial PEXEL motifs have been identified in the amino terminal domain of the PNEPs REX2 (LAE) [43] and SBP1 (LAD) [44] that are essential for export. Inspection of the PF14_0369 amino terminal domain identified a partial PEXEL motif identical to the important LAD motif identified in SBP1. Analysis of the essential transmembrane domains from SBP1 and REX2 highlighted a relative abundance of phenylalanine residues [43] also found in the third transmembrane domain of PF14_0369 (Additional file 1).

\section{Discussion}

Maintenance of copper homeostasis is essential for cell survival. Consequently sophisticated mechanisms have evolved for copper acquisition, distribution and excretion. In mammalian cells, copper is acquired by the copper transport protein Ctr1 and distributed to target proteins via dedicated copper metallochaperones such as CCS, Atox1 and Cox17 [7,8]. To avoid the potentially toxic effects of copper, $\mathrm{Cu}$-ATPase proteins mediate the excretion of excess copper [9] and a P. falciparum $\mathrm{Cu}$ ATPase ortholog has been identified [5]. One P. falciparum copper source appears to be from the ingestion of host erythrocyte $\mathrm{Cu} / \mathrm{Zn}$ SOD [5]. A screen of the PlasmoDB database, performed in the present study, identified six P. falciparum copper-requiring protein orthologs and a candidate copper transport protein. Native expression of the putative copper transporter was confirmed by Western blot and the protein's subcellular location identified by immunofluorescence microscopy. A recombinant form of the transporter's amino terminal domain was shown to bind copper in vitro and within $E$. coli host cells, supporting the possibility that the full-length protein functions to acquire copper.

\section{Identification of a putative $P$. falciparum copper transport protein}

The identification of six P. falciparum copper-requiring protein orthologs suggested an important role for copper in P. falciparum metabolism. Treating P. falciparum parasites with the intracellular copper chelator, neocuproine, inhibited ring-to-trophozoite transition in vitro [5], highlighting the importance of copper for the parasite. During the course of its asexual cycle, P. falciparum appears to digest host erythrocyte $\mathrm{Cu} / \mathrm{Zn} \mathrm{SOD}$ to release copper [5]. The presence of a membrane associated copper binding protein with copper transport protein characteristics in plasmodia suggests a mechanism for the transport of copper similar to that played by the Ctr1 copper transport protein in yeast and mammalian cells $[7,8]$. Candidate copper transporter sequences were identified for eight species of the Plasmodium parasite and each sequence was shown to contain the essential and largely definitive $\mathrm{Mx}_{3} \mathrm{M}$ and $\mathrm{Gx}_{3} \mathrm{G}$ motifs (Figure 1B) $[30,45]$. The predicted amino terminal domain of each putative transporter was found to contain one or more methionine motifs (MxM or MxxM). Although not limited to copper transporters, these motifs are important for Ctr1 protein function [30].

The presence of three putative membrane-spanning regions is considered definitive for copper transport proteins [33] and topological analysis of the putative $P$. falciparum copper transporter identified three such domains. Since three transmembrane domains cannot form a functional channel or pore for ion transport [10], a homotrimeric complex of copper transport protein monomers is formed for the characterized mammalian and yeast copper transport proteins [33]. The P. falciparum copper transport protein may form a similar complex since the first transmembrane domain of the copper transport protein family serves as an adaptor allowing evolutionarily distant copper transporters to adopt a similar overall structure [46]. An immunoblot of yeast and mammalian copper transport proteins identified monomeric and dimeric species of the trimeric complex [37]. Similar monomeric and dimeric species were detected in an immunoblot of the putative $P$. falciparum copper transport protein in this study.

\section{Recombinant expression and copper binding to MBP-PfCtr369Nt ${ }^{-\mathrm{s}}$}

Signal peptides, transmembrane domains, rare codons, introns and genome AT-richness affect recombinant expression of $P$. falciparum proteins [34]. The amino terminal signal peptide of the putative $P$. falciparum copper transporter was, therefore, excluded from the expression construct, resulting in periplasmic expression. The purified MBP-PfCtr369 $\mathrm{Nt}^{-\mathrm{S}}$ recombinant protein bound reduced copper in vitro and within a cellular environment. A second copper transport protein, MBPPfCtr211Nt ${ }^{-\mathrm{S}}$, from the PF14_0211 gene was recombinantly expressed and isolated. Expression of the native $P$. falciparum protein encoded by this gene has not been ascertained at this stage.

In mammalian and yeast cells, the reduced cuprous ion $\left(\mathrm{Cu}^{+}\right)$is favoured for transfer and transport [30], since $\mathrm{Cu}^{+}$is more exchange labile than $\mathrm{Cu}^{2+}[36] \cdot \mathrm{Cu}^{+}$is highly reactive in an oxidizing environment and methionine motifs in the extracellular amino terminal domain of the copper transporter family are thought to sequester copper prior to its transport across the lipid bilayer [30]. This was supported by a study demonstrating that methionine motif peptides inhibited copper-catalysed ascorbate oxidation through $\mathrm{Cu}^{+}$chelation [36]. MBPPfCtr369 $\mathrm{Nt}^{-\mathrm{S}}$ inhibited copper-catalysed ascorbate oxidation through copper chelation. Taken together with the data showing copper binding to MBP-PfCtr369Nt ${ }^{-\mathrm{S}}$, 
it appeared that the amino terminal domain of the putative $P$. falciparum copper transporter preferably coordinates the $\mathrm{Cu}^{+}$ion. Copper coordination was presumably a result of the methionine motif present in MBP-PfCtr369Nt ${ }^{-S}$.

The methionine motifs contained in the amino terminal domains of yeast and human copper transport proteins are essential for copper binding under copper limiting conditions [30]. The yeast copper transport protein contains eight methionine motifs, but only the last methionine of the eighth motif was shown by Puig et al. [30] to be essential for copper binding capability. The position of this methionine is conserved between copper transport proteins and is 20 amino acid residues $\mathrm{N}$-terminal to the transporter's first transmembrane domain [30]. Interestingly, the last methionine of the methionine motif in the amino terminal domain of the putative $P$. falciparum copper transport protein is located in a similar position. However, the involvement of other amino acid residues, like cysteine and histidine residues that bind metal ions $[47,48]$, and are present in this protein cannot be excluded. Identification of the specific residues coordinating copper will be explored in future experiments.

\section{MBP-PfCtr369 $\mathrm{Nt}^{-5}$ recombinant protein likely interacts with $E$. coli copper binding proteins}

An interesting consequence of expressing MBP$P f C \operatorname{tr} 369 \mathrm{Nt}^{-\mathrm{S}}$ in the presence of copper was a significant increase in recombinant protein yield. In the presence of excess copper it is a possibility that the copper bound to and stabilized the recombinant protein [48]. The cytoplasm and periplasm of $E$. coli cells do, however, have different copper requirements since almost all bacterial copper proteins, such as multi-copper oxidases, amine oxidases and lysine oxidases are found in the periplasm or excreted extracellularly [49]. Copper availability in $E$. coli is thought to be regulated by the actions of the DNA-binding metal sensor CueR, which controls the expression of genes encoding proteins involved in metal homeostasis [50]. A copper-requiring protein is thought to gain access to copper only if the protein's affinity for the metal ion is greater than the buffered cellular concentration of copper [51]. Interaction of a recombinant $P$. falciparum protein with native $E$. coli proteins has been demonstrated for PfHsp70 [52], supporting the possibility that MBP-PfCtr369Nt ${ }^{-S}$ interacts with native E. coli copper proteins for copper loading. These interactions could, in turn, influence the availability of copper for native E. coli copper-requiring proteins resulting in tightly regulated $\mathrm{MBP}-\mathrm{PfC} \mathrm{Ct} 369 \mathrm{Nt}^{-\mathrm{S}}$ expression under standard growth conditions. The addition of excess extracellular copper appears to have alleviated this growth stress producing the increase in the expression of MBP-PfCtr369 $\mathrm{Nt}^{-\mathrm{S}}$ observed here.

\section{The putative $P$. falciparum copper transport protein shows stage-specific localization}

During early stages of asexual development, the putative $P$. falciparum copper transporter appears to be targeted to the plasma membrane of the infected erythrocyte. As the parasite matures through its asexual cycle the protein was detected on a parasite membrane. This may represent a turnover of host cell membrane associated malarial proteins, followed by trafficking of the copper transporter to a parasite membrane. The precise localization of the copper transporter, when associated with the parasite, was not elucidated, due to limits to the fluorescence detection methods. The parasitophorous vacuolar membrane contains a "promiscuous" pore that permits the passage of solutes, nutrients and macromolecules [53,54] and thus it is unlikely for there to be the need for a separate copper transporter. The parasite plasma membrane contains a variety of selective transporters (Reviewed by Martin et al. [4]). The copper transporter is thus suggested to be associated with the parasite plasma membrane. PfCuP-ATPase was similarly localized to a parasite plasma membrane and the surface of the infected erythrocyte. However, unlike the putative copper transport protein, PfCuP-ATPase was associated with both the parasite plasma membrane and the erythrocyte membrane at the same time in trophozoites and schizonts, whilst no expression was detected in rings [5]. These authors suggested that dual localization of PfCuP-ATPase represents a novel mechanism by which the parasite reduces copper toxicity through copper efflux [5]. Reasons for the different localities of the copper transport protein are less apparent. There is the possibility that during ring stages, extracellular copper is required until the parasite digests endocytosed host cell $\mathrm{Cu} / \mathrm{Zn} \mathrm{SOD}$ and translocates the copper transporter protein to a parasite membrane.

The concentration of copper in normal red blood cells has been reported as18 $\mu \mathrm{M}$ and copper is imported into red cells by a $\mathrm{Cl}^{-}-\mathrm{HCO}_{3}^{-}$anion exchanger [55]. Inside the red cell most of the copper is associated with $\mathrm{Cu} / \mathrm{Zn}$ SOD and a 30 and a $40 \mathrm{kDa}$ red cell protein [56]. Rasoloson et al. [5] reported a lower red cell copper concentration at $10 \mu \mathrm{M}$ and further suggested that copper concentrations in parasitized cells was lower than uninfected cells. Copper in isolated parasites was lower than in red cells at $2 \mu \mathrm{M}$ in rings and between 6 and $6.6 \mu \mathrm{M}$ in trophozoites (depending on the isolation method). This data disagrees with recent data indicating that malaria infected red cell copper concentration was $30 \mu \mathrm{M}$, and double that of uninfected red cells in the same experiment [57]. The different values for copper concentrations in infected red cells may be due to the different measuring methods employed and needs to be reconciled [5,57]. Interestingly as the parasite develops from 
trophozoites to schizonts, the concentration of ingested $\mathrm{Cu} / \mathrm{Zn}$ SOD decreases [5] and this coincides with data presented here showing the appearance of the putative copper transporter on parasite membranes, the highest level of expression of the protein, and mRNA levels described by Le Roch et al. [38]. Thus as the source of copper in the form of $\mathrm{Cu} / \mathrm{Zn}$ SOD decreases in the parasite [5], the parasite compensates with an increase in expression of the putative copper transport protein. Given the potential toxicity of copper and the need for the regulation of copper homeostasis, it is likely that the parasite employs a copper transport protein alongside the PfCuP-ATPase copper export protein described by Rasoloson et al. [5]. It is suggested that, given the presence and membrane location of a copper binding protein with copper transporting motifs, and the increase in copper concentration in malaria infected red cells [57], that the protein described here has a role in copper transport. Data to support a transport role for the copper binding protein is being pursued.

Treatment of $P$. falciparum parasites with neocuproine inhibited ring-to-trophozoite transition [5], implicating copper metabolism as a potential target for novel antimalarial drug development. Copper, when the concentration is above a critical level, has been shown to be toxic to the parasite [58]. However, from in silico findings it seems unlikely that $P$. falciparum contains unique copper-dependent metabolic pathways. Copper-binding protein motifs also appear to be conserved from prokaryotes to eukaryotes [59], suggesting that designing a compound specific for P. falciparum copper-dependent proteins could prove difficult. An alternative approach would be to deliver anti-malarial compounds to the parasite by exploiting transport mechanisms, as suggested for the $P$. falciparum new permeation pathway and choline carrier [60]. The human copper transport protein has been shown to transport the platinum containing anti-cancer drugs cisplatin and oxaliplatin [61]. Cisplatin also exhibits anti-malarial activity through DNA damage $[62,63]$. Given the structural similarities between the putative $P$. falciparum copper transport protein and the human copper transporter, it is possible that cisplatin is delivered to the parasite by the putative copper transport protein. This transport mechanism could perhaps be exploited for the delivery of novel platinum-based anti-malarial compounds.

Plasmodium falciparum actively remodels the erythrocyte during infection, leading to an increase in the permeability of the host cell membrane to low molecular weight solutes [64]. This increase is mediated by 'new permeability pathways' that have also been shown to greatly facilitate the uptake of the antibiotics fosmidomycin and its derivative FR900098 [62]. Parasitized erythrocytes also show a significant increase in the uptake of a copper-neocuproine complex when compared to uninfected erythrocytes [65]. Association of the putative $P$. falciparum copper transport protein with the erythrocyte membrane, during early asexual development, therefore makes it tempting to speculate that the copper transport protein's mechanism accounts for the increased rate of copper-neocuproine complex uptake by parasitized erythrocytes. Complexation of the anti-malarial buparvaquone to copper(II) significantly enhanced its antimalarial activity [66]. This was proposed to be a consequence of improved compound internalisation, which may be related to the transport mechanism of the putative copper transport protein. Localization of the P. falciparum copper transport protein to the erythrocyte and parasite membranes in late ring and early trophozoite stages may explain the increased susceptibility of these stages to cisplatin [67].

\section{The putative copper transport protein sequence lacks an} identifiable export motif

Plasmodium falciparum protein export beyond the parasitophorous vacuole membrane was suggested to be mediated by the PEXEL/HT motif, but this motif was later shown not to be the sole determinant of protein export. Over 300 PEXEL/HT proteins have been predicted, whereas only a few PEXEL negative export proteins (PNEPs) have been identified and a common PNEP motif is yet to be identified [68]. One important feature of PNEP proteins is the presence of a transmembrane domain, since removal of this domain from the PNEPs MAHRP1, SBP1 and REX2 inhibited protein export $[43,44]$. Similarly, the transmembrane domain of SURFIN $_{4.2}$ was essential for protein trafficking to the infected erythrocyte and Maurer's clefts [69].

Analysis of the PNEPs REX2 [43] and SBP1 [44] identified partial PEXEL/HT motifs (LAE and LAD, respectively) as being essential for protein export. Analysis of the PF14_0369 sequence identified an identical LAD motif within the first 20 amino acids of its amino terminal domain, a similar position to the LAD motif in SBP1. Mutational analysis of the related LAE motif in REX2 established that the glutamate residue was essential for export [43]. This suggests the related aspartate residue in the LAD motif of PF14_0369 may be important for export. Cleavage of the signal peptide in the PF14_0369 sequence would generate a new amino terminus similar to that generated following cleavage of the PEXEL motif in PEXEL/HT proteins. PEXEL motif cleavage generates an $\mathrm{xD} / \mathrm{E} / \mathrm{Q}$ amino terminus, with the presence of $D / E / Q$ being essential for protein export [70]. Another potential export signal in SBP1 is located $\mathrm{N}$-terminal of its transmembrane domain, between amino acids 180 and 190 [44]. A comparison of this short signal sequence (NEYEVES) with the PF14_0369 
sequence identified a similar sequence upstream of the first predicted transmembrane domain (NKWETKS), thereby implicating this sequence as a potential contributor to successful protein export. The presence of motifs in PF14_0369 similar to those important for PNEP export suggests that these motifs play a role in the export of the putative copper transporter.

The amino terminal domain of the P. falciparum copper binding protein described here binds copper in vitro and in an in vivo expression system. The protein has copper transport motifs and has been shown to be expressed by malaria parasites and locate to two different membranes (the erythrocyte and the parasite membrane) as the parasite develops within the infected red cell. This evidence implicates a copper transport role for the protein in malaria infected erythrocytes and this implication is being explored. Whether the protein imports copper or has a copper export role alongside the $\mathrm{Cu}$-ATPase protein described by others [5], remains to be elucidated.

\section{Conclusions}

A putative $P$. falciparum copper transport protein was identified and showed that the recombinant amino terminal domain binds copper in vitro and within E. coli host cells. This ability, combined with conserved copper transport protein sequence features, suggest an additional malaria copper transport mechanism to that previously described [5]. Interestingly, the putative $P$. falciparum copper transport protein initially localized to the erythrocyte membrane and then relocated to a parasite membrane through the course of asexual development. The presence of a putative malaria copper transport protein has interesting implications for malaria copper metabolism and the protein may have a potential role as a novel anti-malarial drug delivery system.

\section{Additional files}

Additional file 1: Important features of the PF14_0369 amino acid sequence. Important features of the PF14_0369 amino acid sequence include a predicted $\mathrm{N}$-terminal signal peptide (underlined), three transmembrane domains (black boxes and numbered 1,2,3), an essential methionine residue $\mathbf{M}, 20$ amino acids $\mathrm{N}$-terminal of the first transmembrane domain, and the $M X_{3} M$ and $G X_{3} G$ motifs. Features thought to contribute to protein trafficking include a partial PEXEL motif (LAD) in the signal peptide and an enrichment of phenylalanine residues (F) in the third transmembrane domain.

Additional file 2: Expression and purification of recombinant MBP$P f C t r 211 \mathrm{Nt}^{-5}$. Expression of MBP-PfCtr211 $\mathrm{Nt}^{-5}$ was targeted to the E. coli periplasm. Steps in the isolation of recombinant MBP-PfCtr211 Nt ${ }^{-5}$ were analysed on a 10\% reducing SDS-PAGE. Lane 1 and 2, total E. coli lysate; lane 3, periplasmic proteins; lane 4 represents proteins that did not bind and lanes 5-10 show protein eluted off the amylose resin. Fermentas unstained protein marker standards are shown to the left of each image.

\section{Abbreviations}

Atox1: Antioxidant protein 1; BCA: Bicinchoninic acid; CCO: Cytochrome-C oxidase; CCS: Copper chaperone for superoxide dismutase; Ctr1: Copper transport protein 1; Cu/Zn SOD: Cuprozinc superoxide dismutase; Exp1: Export protein 1; GAPDH: Glyceraldehyde 3-phosphate dehydrogenase; $\mathrm{H}_{2}$ Asc: Ascorbic acid; HSP 86/90: Heat shock protein 86/90; LDH: Lactate dehydrogenase; MAHRP1: Membrane-associated histidine-rich protein 1; MBP: Maltose binding protein; PEXEL/HT: Plasmodium export element/host targeting signal; PfCtr369 $\mathrm{Nt}^{-5}$ : Plasmodium falciparum copper transport protein PF14_0369 amino terminal domain minus signal peptide; PNEP: PEXEL negative exported protein; REX2: Ring exported protein 2; SBP1: Skeleton binding protein 1 .

\section{Competing interests}

The authors declare that they have no competing interests.

\section{Authors' contributions}

All authors contributed to planning the experimental strategy, analysing the data and writing the paper. DLC conducted the experiments with the guidance of JPDG. DLC conducted the immunofluorescence experiments with help from JMP. All authors read and approved the final manuscript.

\section{Acknowledgements}

Our thanks to Peter Smith (University of Cape Town) for providing us with the P. falciparum D10 cultures and to Rob Skilton (International Livestock Research Institute) for supplying the T. parva gene sequence. We thank Prof Theresa Coetzer for critical reading of the manuscript.

\section{Funding}

We would like to thank the South African Department of Science and Technology S.A. Malaria Initiative, S.A .National Research Foundation, the S.A . Medical Research Council and the UKZN Research Incentive Fund for financial support. JMP is supported by the DFG German-Africa projects in Infectology programme.

\section{Author details}

${ }^{1}$ Biochemistry, University of KwaZulu-Natal, P.B. X01, Carbis Road, Scottsville 3209, South Africa. ${ }^{2}$ Parasitology, Faculty of Biology, Philipps University Marburg, Karl von Frisch Str. 8, Marburg D-35043, Germany.

Received: 3 October 2012 Accepted: 20 November 2012

Published: 29 November 2012

\section{References}

1. WHO: World Malaria Report. Geneva: World Health Organization; 2011. http://who.int/malaria/world_malaria_report_2011/en/.

2. Wells TN, Poll EM: When is enough enough? The need for a robust pipeline of high-quality antimalarials. Discov Med 2010, 9:389-398.

3. Staines HM, Derbyshire ET, Slavic K, Tattersall A, Vial H, Krishna S: Exploiting the therapeutic potential of Plasmodium falciparum solute transporters. Trends Parasitol 2010, 26:284-296.

4. Martin RE, Ginsburg H, Kirk K: Membrane transport proteins of the malaria parasite. Mol Microbiol 2009, 74:519-528.

5. Rasoloson D, Shi L, Chong CR, Kafsack BF, Sullivan DJ: Copper pathways in Plasmodium falciparum infected erythrocytes indicate an efflux role for the copper P-ATPase. Biochem J 2004, 381(Pt 3):803-811.

6. Halliwell B, Gutteridge JM: Oxygen toxicity, oxygen radicals, transition metals and disease. Biochem J 1984, 219:1-14.

7. Kim BE, Nevitt T, Thiele DJ: Mechanisms for copper acquisition, distribution and regulation. Nat Chem Biol 2008, 4:176-185.

8. Lutsenko S: Human copper homeostasis: a network of interconnected pathways. Curr Opin Chem Biol 2010, 14:211-217.

9. Tapiero H, Townsend DM, Tew KD: Trace elements in human physiology and pathology. Copper. Biomed Pharmacother 2003, 57:386-398.

10. Nose $Y$, Rees EM, Thiele DJ: Structure of the Ctr1 copper trans'PORE'ter reveals novel architecture. Trends Biochem Sci 2006, 31:604-607.

11. Turski ML, Thiele DJ: Drosophila Ctr1A functions as a copper transporter essential for development. J Biol Chem 2007, 282:24017-24026.

12. Wu X, Sinani $D$, Kim H, Lee J: Copper transport activity of yeast Ctr1 is down-regulated via its $C$ terminus in response to excess copper. J Biol Chem 2009, 284:4112-4122.

13. Plasmodium Genomics Resource. http:www.plasmodb.org. 
14. Toye P, Nyanjui J, Goddeeris B, Musoke AJ: Identification of neutralization and diagnostic epitopes on PIM, the polymorphic immunodominant molecule of Theileria parva. Infect Immun 1996, 64:1832-1838.

15. Tusnady GE, Simon I: The HMMTOP transmembrane topology prediction server. Bioinformatics 2001, 17:849-850.

16. Krogh A, Larsson B, von Heijne G, Sonnhammer EL: Predicting transmembrane protein topology with a hidden Markov model: application to complete genomes. J Mol Biol 2001, 305:567-580.

17. Carmenes RS, Freije JP, Molina MM, Martin JM: Predict7, a program for protein structure prediction. Biochem Biophys Res Commun 1989, 159:687-693.

18. Hurdayal R, Achilonu I, Choveaux D, Coetzer THT, Goldring JPD: Anti-peptide antibodies differentiate between plasmodial lactate dehydrogenases. Peptides 2010, 31:525-532.

19. Reininger $L$, Billker $O$, Tewari R, Mukhopadhyay A, Fennell C, Dorin-Semblat D, Doerig C, Goldring D, Harmse L, Ranford-Cartwright L, Packer J, Doerig, C: A NIMA-related protein kinase is essential for completion of the sexual cycle of malaria parasites. J Biol Chem 2005, 280:31957-31964.

20. French C, Keshavarz-Moore E, Ward JM: Development of a simple method for the recovery of recombinant proteins from Escherichia coli periplasm. Enzyme Microb Technol 1996, 19:332-338.

21. Laemmli UK: Cleavage of structural proteins during the assembly of the head of bacteriophage T4. Nature 1970, 227:680-685.

22. Towbin H, Staehelin T, Gordon J: Electrophoretic transfer of proteins from polyacrylamide gels to nitrocellulose sheets: procedure and some applications. Proc Natl Acad Sci USA 1979, 76:4350-4354.

23. Goldring JP: Protein quantification methods to determine protein concentration prior to electrophoresis. Methods Mol Biol 2012, 869:29-35.

24. Spork S, Hiss JA, Mandel K, Sommer M, Kooij TW, Chu T, Schneider G, Maier UG, Przyborski JM: An unusual ERAD-like complex is targeted to the apicoplast of Plasmodium falciparum. Eukaryot Cell 2009, 8:1134-1145.

25. Lambros C, Vanderberg JP: Synchronization of Plasmodium falciparum erythrocytic stages in culture. J Parasitol 1979, 65:418-420

26. Brenner AJ, Harris ED: A quantitative test for copper using bicinchoninic acid. Anal Biochem 1995, 226:80-84.

27. Tonkin CJ, van Dooren GG, Spurck TP, Struck NS, Good RT, Handman E, Cowman AF, McFadden GI: Localization of organellar proteins in Plasmodium falciparum using a novel set of transfection vectors and a new immunofluorescence fixation method. Mol Biochem Parasitol 2004, 137:13-21.

28. Tsukihara T, Aoyama H, Yamashita E, Tomizaki T, Yamaguchi H, Shinzawa-Itoh K, Nakashima R, Yaono R, Yoshikawa S: The whole structure of the 13-subunit oxidized cytochrome c oxidase at 2.8 A. Science 1996, 272:1136-1144.

29. Horng Y-C, Cobine PA, Maxfield AB, Carr HS, Winge DR: Specific copper transfer from the Cox17 metallochaperone to both Sco1 and Cox11 in the assembly of yeast cytochrome C oxidase. J Biol Chem 2004, 279:35334-35340.

30. Puig S, Lee J, Lau M, Thiele DJ: Biochemical and genetic analyses of yeast and human high affinity copper transporters suggest a conserved mechanism for copper uptake. J Biol Chem 2002, 277:26021-26030.

31. Escalante AA, Ayala FJ: Evolutionary origin of Plasmodium and other Apicomplexa based on rRNA genes. Proc Natl Acad Sci USA 1995, 92:5793-5797.

32. Rathore D, Wahl AM, Sullivan M, McCutchan TF: A phylogenetic comparison of gene trees constructed from plastid, mitochondrial and genomic DNA of Plasmodium species. Mol Biochem Parasitol 2001, 114:89-94.

33. De Feo CJ, Aller SG, Siluvai GS, Blackburn NJ, Unger VM: Three-dimensional structure of the human copper transporter hCTR1. Proc Natl Acad Sci USA 2009, 106:4237-4242.

34. Vedadi M, Lew J, Artz J, Amani M, Zhao Y, Dong A, Wasney GA, Gao M, Hills T, Brokx S, Qiu W, Sharma S, Diassiti A, Alam Z, Melone M, Mulichak A, Wernimont A, Bray J, Loppnau P, Plotnikova O, Newberry K, Sundararajan E, Houston S, Walker J, Tempel W, Bochkarev A, Kozieradzki I, Edwards A, Arrowsmith C, Roos D, Kain K, Hui R: Genome-scale protein expression and structural biology of Plasmodium falciparum and related Apicomplexan organisms. Mol Biochem Parasitol 2007, 151:100-110.

35. Lutsenko S, Petrukhin K, Cooper MJ, Gilliam CT, Kaplan JH: N-terminal domains of human copper-transporting adenosine triphosphatases (the Wilson's and Menkes disease proteins) bind copper selectively in vivo and in vitro with stoichiometry of one copper per metal-binding repeat. J Biol Chem 1997, 272:18939-18944.

36. Jiang J, Nadas IA, Kim MA, Franz KJ: A Mets motif peptide found in copper transport proteins selectively binds $\mathrm{Cu}(\mathrm{I})$ with methionine-only coordination. Inorg Chem 2005, 44:9787-9794

37. Lee J, Pena MM, Nose $Y$, Thiele DJ: Biochemical characterization of the human copper transporter Ctr1. J Biol Chem 2002, 277:4380-4387.

38. Le Roch KG, Zhou Y, Blair PL, Grainger M, Moch JK, Haynes JD, De La Vega P, Holder AA, Batalov S, Carucci DJ, Wenzler EA: Discovery of gene function by expression profiling of the malaria parasite life cycle. Science 2003, 301:1503-1508.

39. Emanuelsson O, Brunak S, von Heijne G, Nielsen H: Locating proteins in the cell using TargetP, SignalP and related tools. Nat Protoc 2007, 2:953-971.

40. Foth BJ, Ralph SA, Tonkin CJ, Struck NS, Fraunholz M, Roos DS, Cowman AF, McFadden Gl: Dissecting apicoplast targeting in the malaria parasite Plasmodium falciparum. Science 2003, 299:705-708.

41. Gunther K, Tummler M, Arnold HH, Ridley R, Goman M, Scaife JG, Lingelbach K: An exported protein of Plasmodium falciparum is synthesized as an integral membrane protein. Mol Biochem Parasitol 1991, 46:149-157.

42. Spielmann T, Hawthorne PL, Dixon MW, Hannemann M, Klotz K, Kemp DJ, Klonis N, Tilley L, Trenholme KR, Gardiner DL: A cluster of ring stagespecific genes linked to a locus implicated in cytoadherence in Plasmodium falciparum codes for PEXEL-negative and PEXEL-positive proteins exported into the host cell. Mol Biol Cell 2006, 17:3613-3624.

43. Haase S, Herrmann S, Gruring C, Heiber A, Jansen PW, Langer C, Treeck M, Cabrera A, Bruns C, Struck NS, Kono M, Engelberg K, Ruch U, Stunnenberg $H G$, Gilberger TW, Spielmann T: Sequence requirements for the export of the Plasmodium falciparum Maurer's clefts protein REX2. Mol Microbiol 2009, 71:1003-1017.

44. Saridaki T, Frohlich KS, Braun-Breton C, Lanzer M: Export of PfSBP1 to the Plasmodium falciparum Maurer's clefts. Traffic 2009, 10:137-152.

45. Aller SG, Eng ET, De Feo CJ, Unger VM: Eukaryotic CTR copper uptake transporters require two faces of the third transmembrane domain for helix packing, oligomerization, and function. J Biol Chem 2004, 279:53435-53441.

46. De Feo CJ, Mootien S, Unger VM: Tryptophan scanning analysis of the membrane domain of CTR-copper transporters. J Membr Biol 2010, 234:113-123.

47. Davis AV, O'Halloran TV: A place for thioether chemistry in cellular copper ion recognition and trafficking. Nat Chem Biol 2008, 4:148-151.

48. Hodak M, Chisnell R, Lu W, Bernholc J: Functional implications of multistage copper binding to the prion protein. Proc Natl Acad Sci USA 2009, 106:11576-11581.

49. Rensing C, Grass G: Escherichia coli mechanisms of copper homeostasis in a changing environment. FEMS Microbiol Rev 2003, 27:197-213.

50. Waldron KJ, Rutherford JC, Ford D, Robinson NJ: Metalloproteins and metal sensing. Nature 2009, 460:823-830

51. Foster AW, Robinson NJ: Promiscuity and preferences of metallothioneins: the cell rules. BMC Biol 2011, 9:25.

52. Shonhai A, Boshoff A, Blatch GL: Plasmodium falciparum heat shock protein 70 is able to suppress the thermosensitivity of an Escherichia coli DnaK mutant strain. Mol Genet Genomics 2005, 274:70-78.

53. Desai SA, Krogstad DJ, McCleskey EW: A nutrient-permeable channel on the intraerythrocytic malaria parasite. Nature 1993, 362:643-646.

54. Spielmann T, Montagna GN, Hecht L, Matuschewski K: Molecular make-up of the Plasmodium parasitophorous vacuolar membrane. Int J Med Microbiol 2012, 302:179-186.

55. Alda JO, Garay R: Chloride (or bicarbonate)-dependent copper uptake through the anion exchanger in human red blood cells. Am J Physiol 1990, 259(4 Pt 1):C570-C576.

56. Speisky H, Navarro P, Cherian MG, Jimenez I: Copper-binding proteins in human erythrocytes: searching for potential biomarkers of copper overexposure. BioMetals 2003, 16:113-123.

57. Marvin RG, Wolford JL, Kidd MJ, Murphy S, Ward J, Que EL, Mayer ML, Penner-Hahn JE, Haldar K, O'Halloran TV: Fluxes in "free" and total zinc are essential for progression of intraerythrocytic stages of Plasmodium falciparum. Chem Biol 2012, 19:731-741.

58. Rosenberg E, Litus I, Schwarzfuchs N, Sinay R, Schlesinger P, Golenser J, Baumeister S, Lingelbach K, Pollack Y: pfmdr2 confers heavy metal resistance to Plasmodium falciparum. J Biol Chem 2006, 281:27039-27045. 
59. Andreini C, Banci L, Bertini I, Rosato A: Occurrence of copper proteins through the three domains of life: a bioinformatic approach. $J$ Proteome Res 2008, 7:209-216.

60. Biagini GA, Ward SA, Bray PG: Malaria parasite transporters as a drugdelivery strategy. Trends Parasitol 2005, 21:299-301.

61. Howell SB, Safaei R, Larson CA, Sailor MJ: Copper transporters and the cellular pharmacology of the platinum-containing cancer drugs. Mol Pharmacol 2010, 77:887-894.

62. Baumeister S, Wiesner J, Reichenberg A, Hintz M, Bietz S, Harb OS, Roos DS, Kordes M, Friesen J, Matuschewski K, Lingelbach K, Jomaa H, Seeber F: Fosmidomycin uptake into Plasmodium and Babesia-infected erythrocytes is facilitated by parasite-induced new permeability pathways. PLoS One 2011, 6:e19334.

63. Murray V, Campbell HM, Gero AM: Plasmodium falciparum: DNA sequence specificity of cisplatin and cisplatin analogues. Exp Parasitol 2011, 128:396-400.

64. Tilley L, Dixon MW, Kirk K: The Plasmodium falciparum-infected red blood cell. Int J Biochem Cell Biol 2011, 43:839-842.

65. Scheibel LW, Rodriguez S: Antimalarial activity of selected aromatic chelators V. Localization of $59 \mathrm{Fe}$ in Plasmodium falciparum in the presence of oxines. Prog Clin Biol Res 1989, 313:119-149.

66. Gokhale NH, Padhye SB, Croft SL, Kendrick HD, Davies W, Anson CE, Powell AK: Transition metal complexes of buparvaquone as potent new antimalarial agents. 1. Synthesis, X-ray crystal-structures, electrochemistry and antimalarial activity against Plasmodium falciparum. J Inorg Biochem 2003, 95:249-258.

67. Nair L, Bhasin VK: Cure with cisplatin (II) or murine malaria infection and in vitro inhibition of a chloroquine-resistant Plasmodium falciparum isolate. Jpn J Med Sci Biol 1994, 47:241-252.

68. Spielmann T, Gilberger TW: Protein export in malaria parasites: do multiple export motifs add up to multiple export pathways? Trends Parasitol 2009, 26:6-10.

69. Alexandre JS, Yahata K, Kawai S, Torii M, Kaneko O: PEXEL-independent trafficking of Plasmodium falciparum SURFIN4.2 to the parasite-infected red blood cell and Maurer's clefts. Parasitol Int 2011, 60:313-320.

70. Boddey JA, Moritz RL, Simpson RJ, Cowman AF: Role of the Plasmodium export element in trafficking parasite proteins to the infected erythrocyte. Traffic 2009, 10:285-299.

doi:10.1186/1475-2875-11-397

Cite this article as: Choveaux et al.: A Plasmodium falciparum copperbinding membrane protein with copper transport motifs. Malaria Journal 2012 11:397.

\section{Submit your next manuscript to BioMed Central and take full advantage of:}

- Convenient online submission

- Thorough peer review

- No space constraints or color figure charges

- Immediate publication on acceptance

- Inclusion in PubMed, CAS, Scopus and Google Scholar

- Research which is freely available for redistribution 